2017 Vol 1. No II

\title{
UPAYA MEMINIMUMKAN AGENCY PROBLEM DENGAN MENGGUNAKAN KONSEP ISLAM TENTANG PERUSAHAAN
}

\author{
Moh. Khoiruddin
}

\begin{abstract}
Although companies generally have goals, in company management practices, conflicts often arise between shareholders as stakeholders and managers, and / or between shareholders and creditors. Agency problems can be experienced by companies that are operationalized with conventional concepts or those based on sharia. Conventionally, agency problem solutions can only be approached with material or incentive-oriented approaches. From the results of a number of studies, it is concluded that an incentive approach alone does not significantly reduce agency problems in the company.

In the sharia concept, the anticipation process for agency problems is carried out from the start of an agreed business contract on the basis of mutual trust and trust. The approach used is not only material but also immaterial, which is oriented towards the afterlife. The moral hazard control system does not only arise from the rules made but also inherently from all parties who agree to the contract. It is possible to achieve higher supervisory cost efficiency in theory with this sharia concept.
\end{abstract}

Keywords: Agency Problem, Moral Hazard and Control System 


\section{Journal Competency of Business}

\section{Vol 1. No II}

\section{Pendahuluan}

Pada umumnya secara knvensional, suatu perusahaan komersial mengelola keuangannya dengan tujuan utama untuk memaksimumkan kesejahteraan para pemegang saham, yang berarti bagaimana meningkatkan pertumbuhan nilai perusahaan yang biasanya diproksi dengan kinerja harga saham perusahaan, namun dalam praktik pengelolaan perusahaan sering muncul konflik anatar pemegang saham sebagai stockholder dengan manajer, dan atau antara pemegang saham dengan kreditur.

Manajer diangkat dan diberi kekuasaan oleh pemegang saham untuk merealisasikan tujuan perusahaan, dan sudah sewajarnya bila manajer bertindak mengambil keputusan terbaik dalam rangka pencapaian tujuan perusahaan sesuai dengan kepentingan para pemegang saham. Namun demikian dalam kenyataannya tidak selamanya, seorang manajer perusahaan akan bertindak sesuai dengan tujuan utama perusahaan tersebut. Hal ini tidak dapat dilepaskan dari motivasi kepentingan manajer secara pribadi dalam perusahaan. Kondisi seperti itu sering memunculkan ketegangan atau konflik kepentingan antara dua belah pihak, yaitu pihak pemegang saham dan pihak manajer (agency problem).Dalam suatu perusahaan di mana pemegang saham sekaligus bertindak sebagai manajer, maka tidak akan ada perbedaan kepentingan. Agency problem jenis ini biasanya terdapat dalam perusahaan yang mengangkat manajer dan ketika kepemilikan manajer atas saham perusahaan yang dipimpinnya kurang dari seratus persen. Proporsi kepemilikan manajer atas saham perusahaan yang relatif kecil terutama pada perusahaan-perusahaan berskala besar sangat berpotensi memunculkan konflik ini.

Selanjutnya, agency problem antara pemegang saham dan kreditur terjadi ketika kreditur di satu sisi mempunyai hak atas sebagian laba yang diperoleh perusahaan dan sebagian asset perusahaan terutama dalam kasus kebangkrutan. Sementara itu di sisi lain pemegang saham melalui manajer memegang pengendalian perusahaan dan sangat mungkin akan menentukan profitabilitas dan risiko perusahaan. Ketika pemegang saham memutuskan untuk melakukan ekspansi usaha, dan bila berhasil, maka hanya pemegang saham yang diuntungkan, kreditur tidak akan mendapatkan dari hasil ekspansi. Selanjutnya, dari sisi kreditur ekspansi usaha tersebut berarti risiko asset perusahaan meningkat apalagi bila perusahaan mengalami kegagalan, sehingga hal itu mendorongnya untuk meningkatkan tingkat keuntungan yang disyaratkan atas 


\section{Vol 1. No II}

kredit yang diberikannya, serta pembatasan atau bahkan penutupan akses kredit bagi perusahaan yang berakibat semakin kecilnya jumlah hutang yang diterima.

Adanya agency problem dan kemungkinan munculnya moral hazard manajer yang berada di luar kemampuan pemegang saham dalam mengawasinya jelas tidak menguntungkan perusahaan, sehingga perlu diminimalkan. Upaya untuk meminimumkan agency problem akan memunculkan agency cost yang harus disediakan pemegang saham dalam jumlah yang tidak kecil. Agency cost tersebut diantaranya untuk keperluan memonitoring kinerja manajer agar sesuai dengan keinginan stockholdertermasuk biaya auditing dan pengendalian internal, pemberian insentif atau kompensasi kepada manajer, serta kontrak dengan pihak ketiga untuk mengantisipasi kemungkinan manajer tidak jujur sehingga membawa kerugian bagi perusahaan di masa yang akan datang.

Dalam perusahaan dengan prinsip konvensional munculnya agency problem merupakan hal yang lazim terjadi. Bagaimana dengan perusahaan yang mendasarkan pada prinsip syariah Islam, apakah agency problem dapat dihilangkan atau diminimalkan secara lebih baik dibandingkan dalam perusahaan konvensional. Tulisan ini mencoba untuk menelaah masalah tersebut. Pada bagian awal terlebih dahulu akan dibicarakan prinsip dan tujuan perusahaan konvensional dan perusahaan yang berlandaskan syariah Islam. Kemudian dilanjutkan dengan solusi yang ditawarkan untuk mengatasi agency problem yang didasarkan pada konsep konvensional serta yang berdasarkan syariah.

\section{Prinsip dan Tujuan Dasar Perusahaan Konvensional}

Terdapat tiga bentuk umum perusahaan, yaitu perusahaan perseorangan (sole proprietorship), perusahaan persekutuan (partnership), dan perseroan terbatas atau corporation (lihat Brigham dan Gapenski 1997).Perusahaan perseorangan merupakan suatu usaha yang dimiliki dan dikelola oleh satu orang untuk memperoleh keuntungan bagi dirinya. Karakteristik umum dari jenis perusahaan ini adalah sebagai berikut:

- Mudah dan murah pembentukannya

- Pemilik mengendalikan langsung perusahaan

- Tidak begitu terpengaruh aturan pemerintah 


\section{Vol 1. No II}

- Pemilik menikmati semua keuntungan dan menanggung semua kerugian

- Bebas pajak penghasilan

- Kesulitan mendapatkan dana dalam jumlah besar

- Usia perusahaan sangat tergantung usia pemilik

- Pemilik bertanggung jawab tak terbatas atas hutang perusahaan

- Keterbatasan keahlian pengelolaan perusahaan

Perusahaan persekutuan merupakan bentuk usaha yang dilakukan oleh beberapa orang secara bersama-sama, dan diformalkan dengan membentuk suatu badan usaha. Karakteristik umum dari jenis perusahaan ini adalah sebagai berikut:

- Mudah dalam pembentukannya

- Relatif mendapatkan dana daripada perusahaan perseorangan

- Keahlian pengelolaan tersedia lebih banyak

- Usia perusahaan terbatas pada usia dan waktu kepesertaan anggota persekutuan

- Pajak penghasilan rendah

- Semua yang bersekutu menandatangani perjanjian secara formal

- Pemilik bertanggung jawab tak terbatas atas hutang perusahaan

- Fleksibilitas yang rendah terhadap perubahan kepemilikan dan keanggotaan

- Masalah yang dihadapi lebih kompleks daripada perusahaan perseorangan

Sementara itu, perusahaan perseroan terbatas merupakan badan usaha yang didirikan dan disahkan secara hukum, didalam terdapat pemisahan antara manajer dan pemilik. Karakteristik umum dari jenis perusahaan ini adalah sebagai berikut:

- Lebih sulit dan berbiaya dalam pembentukannya

- Pemilik bertanggung jawab terbatas atas hutang perusahaan

- Usia perusahaan tidak terbatas pada usia dan waktu kepesertaan pemilik

- Relatif mudah mendapatkan dana dari penjualan saham dan obligasi

- Fleksibilitas yang tinggi terhadap perubahan kepemilikan dengan penjualan saham di bursa

- Keahlian pengelolaan tersedia banyak

- Pembayaran pajak lebih besar 


\section{Vol 1. No II}

- Kemungkinan munculnya agency problem

Semua bentuk perusahaan di atas dibentuk dalam rangka untuk mencapai tujuan yang telah ditetapkan. Tujuan dari semua bentuk perusahaan tersebut harus jelas dan terukur. Perusahaan berdasarkan pada tujuan yang dapat diukur, ukurannya serta kelemahannya secara ringkas dapat kita lihat pada tabel di bawah ini:

Tabel 1. Iktisar Tujuan Perusahaan

\begin{tabular}{|c|c|c|c|}
\hline Tujuan Perusahaan & $\begin{array}{c}\text { Terkait dengan } \\
\text { Pertanyaan }\end{array}$ & Ukurannya & Kelemahannya \\
\hline $\begin{array}{l}\text { - Profit } \\
\text { Maximization }\end{array}$ & $\begin{array}{l}\text { Bagaimana } \\
\text { menghasilkan laba } \\
\text { bersih sebesar dan } \\
\text { secepat mungkin }\end{array}$ & $\begin{array}{l}\text { - Peningkatan laba } \\
\text { bersih/tahun } \\
\text { - peningkatanEPS }\end{array}$ & $\begin{array}{l}\text { Seringkali } \\
\text { mengabaikan risiko } \\
\text { yang mungkin terjadi } \\
\text { pada investasi yang } \\
\text { dilakukan. }\end{array}$ \\
\hline $\begin{array}{l}\text { - Maximization of } \\
\text { Return on } \\
\text { Investment }\end{array}$ & $\begin{array}{l}\text { Bagaimana } \\
\text { memperoleh return } \\
\text { investasi yang } \\
\text { maksimum dari } \\
\text { setiap rupiah dana } \\
\text { yang diinvestasikan }\end{array}$ & $\begin{array}{l}\text { Peningkatan laba } \\
\text { bersih per total } \\
\text { investasi }\end{array}$ & $\begin{array}{l}\text { Seringkali } \\
\text { mengabaikan risiko } \\
\text { yang mungkin terjadi } \\
\text { pada investasi yang } \\
\text { dilakukan. }\end{array}$ \\
\hline $\begin{array}{l}\text { - Maximization of } \\
\text { Shareholder } \\
\text { Wealth }\end{array}$ & $\begin{array}{l}\text { Bagaimana } \\
\text { menghasilkan } \\
\text { prospek cerah } \\
\text { perusahaan di masa } \\
\text { depan, melalui } \\
\text { kombinasi keputusan } \\
\text { pendanaan, investasi } \\
\text { dan pembagian } \\
\text { dividen }\end{array}$ & $\begin{array}{l}\text { Harga saham yang } \\
\text { maksimal }\end{array}$ & $\begin{array}{l}\text { - } \text { Harga saham } \\
\text { juga sering } \\
\text { dipengaruhi oleh } \\
\text { faktor eksternal } \\
\text { yang } \\
\text { uncontrolable } \\
\text { - Perusahaan yang } \\
\text { belum go-public } \\
\text { akan mengalami } \\
\text { kesulitan }\end{array}$ \\
\hline
\end{tabular}


2017 Vol 1. No II

\begin{tabular}{|l|l|l|l|}
\hline & & - Jaminan & \\
& Bagaimana & pelayanan yang & \\
& menerapkan social & terbaik & Extracost sehingga \\
- Social Goals & responsibility untuk & - Jenjang karir dan & rentan muncul \\
& melindungi & gaji yang fair & konflik antara social \\
& kepentingan & Penggunaan & goalsdengan \\
& stakeholder & produk yang & \\
& ramah lingkungan & \\
\hline
\end{tabular}

\section{Prinsip Dasar Syariah dalam Kontrak Bisnis}

Beberapa prinsip dasar syariah Islam yang melandasi kontrak bisnis yang dilakukan oleh semua pihak yang melakukan kegiatan usaha bisnis antara lain sebagai berikut:

a. Ketentuan dan kondisi suatu kontrak kerjasama seharusnya didesain sedemikian rupa sehingga dapat menghindari kemungkinan perselisihan selama bisnis berlangsung atau saat waktu pembagian keuntungan atau saat menderita kerugian.

b. Modal bisnis seharusnya dinyatakan dalam bentuk uang. Bila sejumlah partner bekerjasama dengan memasukkan bisnisnya atau komoditi atau nilai kekayaan bisnisnya, maka komoditi atau kekayaan tersebut seharusnya ditentukan dalam nilai uang dan jumlah tersebut harus diperhitungkan sebagai kontribusi dan partner.

c. Dalam kerjasama, hubungan antar partner dalah hubungan antara principal dan agent.

d. Pemilik modal dan tenaga kerja secara bersama bertanggung jawab untuk menciptakan laba serta dalam pembagian keuntungan.

e. Hak dan tanggung jawab partner tergantung pada sifat dari kerjasama bisnis yang disepakati, dan seberapa besar bisnis dikelola kebiasaan, kesepakatan dan pemanfaatan kemampuan yang ada. Dalam hal ini perhatian pada kepentingan bisnis merupakan kriteria terpenting dalam penentuan hak dan kewajiban dari partner.

f. Hak harus seiring dengan tanggung jawab. Partner tidak aktif tidak diijinkan mengikat perusahaan dengan kepentingannya. Partner tersebut tidak akan menuntut pendapatan tetap dari pekerjaannya kecuali bagian dari laba, namun para tenaga kerja akan menerima upah dari pendapatan usaha bisnis tersebut. 


\section{Journal Competency of Business}

2017 Vol 1. No II

g. Dalam kerjasama bisnis, partner dengan kontribusi tenaga kerja yang lebih tinggi diperbolehkan mendapatkan bagian laba yang lebih tinggi meskipun kontribusi modalnya lebih sedikit daripada yang lainnya.

h. Tidak ada partner yang mempunyai hak mendapatkan porsi laba secara tetap. Bila bisnis menghasilkan keuntungan, maka semua partner mendapatkan bagian secara proporsional. Bila bisnis menghasilkan keuntungan, maka tidak ada satupun partner yang mendapatkan hak khusus untuk menanggung sebagian kerugian secara ekslusif.

i. Hutang dari para partner ditentukan oleh sifat atau bentuk kerja sama bisnis yang disepakati bersama. 
2017 Vol 1. No II

\section{Klasifikasi Kontrak Bisnis Islami}

Bentuk legal perusahaan atau kontrak bisnis Islami ditentukan oleh bagaimana modal didapatkan, bagaimana tenaga kerja dipekerjakan, bagaimana berbagai faktor dihargai, siapa yang mengambil kebijakan, berapa banyak perusahaan atau kontrak yang disatukan, dan siapa yang menanggung resiko kegagalan.

\begin{tabular}{|c|c|c|}
\hline Dasarnya & Bentuknya & Jenisnya \\
\hline 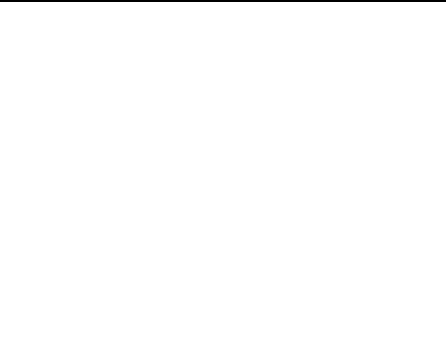 & $\begin{array}{l}\text { - Prinsip Profit/ } \\
\text { Revenue Sharing }\end{array}$ & $\begin{array}{c}\text { Mudhrabah (Jangka Pendek) } \\
-\quad \text { Mudharabah } \\
\text { Muthlaqah } \\
-\quad \text { Mudharabah } \\
\text { Muqayyadah }\end{array}$ \\
\hline $\begin{array}{l}\text { - Direct Financial } \\
\text { Accomodation (Uqud } \\
\text { al-Ishtarak }\end{array}$ & $\begin{array}{l}\text { - Prinsip profit Loss } \\
\text { Sharing }\end{array}$ & $\begin{array}{ll}\text { Musyarakah (Jangka } \\
\text { Panjang) } & \\
- & \text { Syirkat Al-Milk } \\
& \text { (Non-Kontraktual } \\
- & \text { Ikhtiyariyah } \\
& \text { (Voluntary } \\
& \text { Partnership) } \\
- & \text { Jabriyyah } \\
& \text { (Involuntary } \\
& \text { Partnership } \\
- & \text { Syirkat Al-Uqud } \\
& \text { (Kontraktual) } \\
- & \text { Mufawadah } \\
- & \text { Inan } \\
- & \text { Wujuh } \\
- & \text { Abdan } \\
- & \text { Permanen Atau } \\
& \text { Berlanjut }\end{array}$ \\
\hline
\end{tabular}


2017 Vol 1. No II

\begin{tabular}{|c|c|c|}
\hline & & $\begin{array}{l}\text { - } \text { Digressive Atau } \\
\text { Diminishing } \\
-\quad \text { Civil Partnership } \\
\text { Atau Legal } \\
\text { Partnership }\end{array}$ \\
\hline & $\begin{array}{ll}\text { - } & \text { Prinsip Output } \\
& \text { Sharing }\end{array}$ & Muzara'a Musaqaf \\
\hline \multirow{3}{*}{$\begin{array}{l}\text { Indirect Financial } \\
\text { Accomodation (Uqud } \\
\text { al-Muawadhaf) }\end{array}$} & $\begin{array}{l}\text { - } \text { Prinsip berdasarkan } \\
\text { Mark-up } \\
(\text { Murabahah })\end{array}$ & \\
\hline & 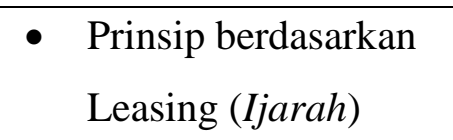 & \\
\hline & $\begin{array}{l}\text { - Prinsip Advace } \\
\text { Purchase }\end{array}$ & Bai-Salam Isthisna' \\
\hline $\begin{array}{l}\text { - Bentuk lain yang } \\
\text { diijinkan }\end{array}$ & 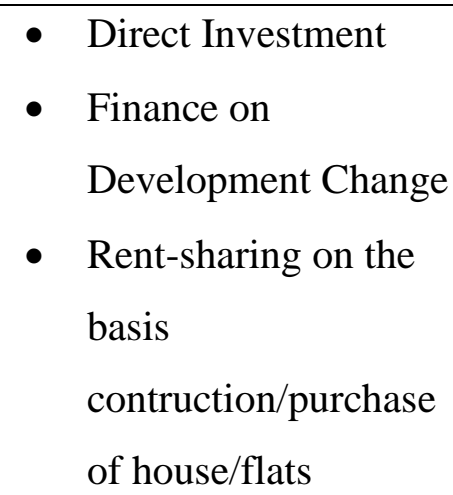 & \\
\hline
\end{tabular}

Sumber: diolah dari M. Abdul Awwal Sarker (1999) dan U. Chapra (2000)

Tipe-tipe kontrak bisnis dan organisasi yang dianggap legal menurut Islam adalah kontrak bisnis yang telah dipraktikkan sebelum dan saat kehidupan Nabi Muhammad SAW, dan tidak dilarang oleh Nabi Muhammad SAW. Kontrak bisnis Islami dapat diklasifikasikan dalam tiga kategori besar, yaitu:

\section{Mudharabah}

Mudharabah merupakan bentuk kemitraan atau kerja sama usaha antara atau kerjasama usaha antara milik dana (shaibul-maal/rabbul-maal) dengan nisbah bagi hasil menurut 


\section{Journal Competency of Business}

\section{Vol 1. No II}

kesepakatan di muka. Istilah mudharabah sering dipakai dalam mazhab Hanafi, Hambali dan Zaidiyah, sementara mazhab Maliki dan Syafi'i sering menggunakan istilah Qiradh untuk menyebut bentuk kemitraan tersebut. Shahibul-maal merupakan mitra pasif, sementara mudharib menyediakan keahlian usaha dan manajemen untuk menjalankan ventura, perdagangan, industri, dan atau jasa dengan tujuan mendapatkan keuntungan sesuai dengan ajaran Islam. Mudharib merupakan pihak yang diberi amanah, dituntut berhati-hati dalam menjalankan usaha, bertanggung jawab atas semua keputusannya, dapat dipercaya, serta bertanggung jawab atas kerugian usaha akibat kelalaiannya. Jika usaha mengalami kerugian, maka seluruh kerugian ditanggung oleh pemilik dana, kecuali bila ditemukan adanya kelalaian atau kesalahan oleh pengelola dana, seperti penyelewengan, kecurangan dan penyalahgunaan dana.Kelalaian atau kesalahan pengelola dana diantaranya dapat ditunjukkan dengan tidak dipenuhinya persyaratan yang ditentukan dalam akad; tidak terdapat kondisi di luar kemampuan (force majeur) yang lazim dan atau yang telah ditentukan dalam akad; atau hasil keputusan dari badan arbitrase atau pengadilan.

Mudharabah terdiri dari dua jenis (PSAK Nomor 59, Akuntansi Perbankan Syariah, 2002), yaitu mudharabah mutlak dan mudharabah muqayyadah. Mudharabah mutlak adalah mudharabah dimana pemilik dana memberikan kebebasan kepada pengelola dana dalam pengelolaan investasinya. Dalam mudharabah ini tidak menyebut secara khusus periode, tempat bisnis, jenis perdagangan tertentu, industri atau jasa, dan pemasok atau pelanggan yang akan dijadikan mitra dagang. Dalam mudharabah yang tidak terikat waktu, maka mudharib memiliki suatu mandat terbuka dan mendapat otoritas melakukan segala sesuatu yang diperlukan oleh bisnis mudharabah. Bila mudharib terbukti lengah, curang atau tidak melaksankan amanah dengan baik, maka dia secara sendiri harus menanggung konsekuensi dan kerugian yang terjadi, tidak dapat dibebankan pada rekening mudharabah.

Sementara mudharabah muqayyadah adalah mudharabah dimana pemilik dana memberikan batasan kepada pengelola dana mengenai tempat, cara dan obyek investasi. Misalnya, pengelola dana dapat diperintahkan untuk tidak mencampurkan dana pemilik dana sengan dana lainnya; tidak menginvestasikan dananya pada transaksi penjualan cicilan, tanpa penjamin, atau tanpa jaminan; mengharuskan pengelola dana untuk melakukan investasi sendiri tanpa melalui pihak ketiga. Mudharabah jenis ini diikat dengan suatu ikatan dan dapat dalam 


\section{Journal Competency of Business}

\section{Vol 1. No II}

bentuk apapun. Dalam mudharabah terikat ini mudharib harus menghormati ikatan yang ditentukan oleh shohibul-maal. Bila mudharib bertindak bertentangan dengan ikatan tersebut, ia bertanggung jawab menanggung konsekuensinya. Dalam mudharabah yang diikat dengan waktu, maka mudharabah dibubarkan bila waktu jatuh temponya telah berakhir. Dalam kasus bank syariah, maka bank dapat bertindak sebagai pemilik dana maupun pengelola dana. Bila bank bertindak sebagai pemilik dana, maka dana yang disalurkan disebut dengan pembiayaan mudharabah. Pengembalian pembiayaan mudharabah dapat dilakukan bersama-sama dengan distribusi bagi hasil atau pada waktu diakhirinya mudharabah. Pada saat mudharabah berakhir sebelum jatuh tempo, dan pembiayaan belum dibayar oleh pengelola dana, maka pembiayaan tersebut diakui sebagai piutang jatuh tempo.

Pada prinsipnya, dalam pembiayaan mudharabah tidak ada jaminan, namun agar pengelola dana tidak melakukan penyimpangan, maka pemilik dana dapat meminta jaminan dari pengelola dana atau pihak ketiga. Jaminan ini hanya dapat dicairkan bila pengelola dana terbukti melakukan pelanggaran terhadap hal-hal yang telah disepakati bersama dalam akad. Pembiayaan mudharabah diakui pada saat pembayaran kas atau penyerahan aktiva non-kas kepada pengelola dana, sementara pembiayaan yang diberikan secara bertahap diakui pada setiap tahap pembayaran atau penyerahan. Pembiayaan mudharabah dalam bentuk kas diukur dari sejumlah uang yang diberikan pemilik dana pada saat pembayaran. Untuk pembiayaan dalam bentuk nonkas diukur sebesar nilai wajar aktiva non-kas pada saat penyerahan. Kemudian, selisih antara nilai wajar dan nilai buku aktiva non-kas diakui sebagai keuntungan atau kerugian pemilik dana. Beban yang terjadi berkaitan dengan mudharabah tidak dapat diakui sebagai bagian pembiayaan mudharabah, kecuali bila telah disepakati bersama antar dua belah pihak. Setiap pembayaran kembali atas pembiayaan mudharabah oleh pengelola dana akan mengurangi saldo pembiayaan tersebut. Dalam kasus terjadinya kehilangan sebagian dana pembiayaan sebelum dimulainya usaha karena adanya kerusakan atau sebab lainnya tanpa adanya kelalaian atau kesalahan pihak pengelola dana, maka kerugian tersebut mengurangi saldo pembiayaan mudharabah dan diakui sebagai kerugian pemilik dana. Namun bila hilangnya setelah dimulainya usaha tanpa adanya kelalaian atau kesalahan pihak pengelola dana, maka kerugian tersebut diperhitungkan pada saat bagi hasil. Demikian pula bila pembiayaan non-kas mengalami penurunan nilai pada saat atau setelah barang dipergunakan secara efektif dalam kegiatan usaha. 


\section{Vol 1. No II}

Setelah melampaui satu periode pelaporan, maka laba atau rugi dapat diketahui dari laporan bagi hasil dari pengelola dana kepada pemilik dana. Laba pembiayaan mudharabah diakui dalam periode terjadinya hak bagi hasil sesuai nisbah yang disepakati. Bagian laba pemilik dana yang tidak dibayarkan oleh pengelola dana pada saat mudharabah selesai atau dihentikan sebelum masanya berakhir diakui sebagai piutang jatuh tempo kepada pengelola dana. Bila ternyata usaha yang dibiayai mengalami kerugian, maka rugi yang terjadi di akui dalam periode terjadinya rugi tersebut dan mengurangi saldo pembiayaan mudharabah. Kerugian akibat penghentian mudharabah sebelum masa akad berakhir diakui sebagai pengurang pembiayaan mudharabah.

Bagi hasil mudharabah dapat dilakukan dengan menggunakan dua metode, yaitu profit sharing dan revenue sharing. Profit sharing dihitung dari pendapatan setelah dikurangi beban yang berkaitan dengan pengelolaan dana mudharabah. Untuk revenue sharing dihitung dari total pendapatan pengelolaan mudharabah.

Dari sisi rugi/laba/biaya, ketentuan-ketentuan lain yang berlaku dalam mudharabah adalah sebagai berikut:

- Kerugian karena kelalaian mudharib tidak dapat dibebankan pada pembiayaan mudharabah

- Pengeluaran personal mudharib tidak dapat dibebankan pada pembiayaan mudharabah

- Semua biaya normal dari bisnis dapat dibebankan pada pembiayaan mudharabah

- Laba bersih dibagi berdasarkan proporsi yang adil yang disepakati sebelumnya dalam perjanjian

- Laba dibagi sesudah kerugian ditutupi

- Laba yang dibagi sebelum penutupan persetujuan mudharabah diperlakukan sebagai hutang

- Untuk mudharabah yang kontinu sebaiknya ada cadangan keuntungan untuk kerugian

Selanjutnya, jika dilihat dari sisi resiko mudharabah, ketentuan-ketentuan yang berlaku adalah sebagai berikut: 


\section{Vol 1. No II}

- Shahibul-maal menanggung resiko modal

- Mudharib menanggung resiko waktu dan usaha

- Bila disetujui semua laba dinikmati mudharib, maka shahibul-maal dipandang sebagai pemberi pinjaman, sehingga mudharib menanggung semua resiko pengembalian modal untuk pembiayaan al-qardhul hasan sesuai dengan perjanjian yang disepakati.

- Bila laba diambil semua oleh shahibul-maal, maka mudharib akan diberi imbalan (ajr al-mitsl) atas jasa-jasanya.

Apabila dilihat dari sisi skala usaha, maka mudharib dilarang melakukan bisnis melebihi dari modal yang diberikan shahibul-maal. Jika mudharib melakukan atas kemauannya sendiri maka dia berhak atas laba usaha ekstranya sekaligus menanggung rugi bila terjadi kerugian usaha. Kemudian, bila dilihat dari sisi barang kerditnya, maka barang kredit yang dibeli dalam kerangka kerelaan dengan shahibul-maalditanggung oleh kedua belah pihak berdasarkan prinsip syirkah-al-wujud.Sementara itu, bila dilihat dari sisi periode mudhrabah, maka mudharabah dibubarkan sesudah penyelesaian ventura yang dilakukan, periode yang ditentukan, kematian salah satu pihak, dan sejak salah satu pihak mengundurkan diri dengan niat membubarkannya.

\section{Musyarakah}

Musyarakah yang sering juga disebut dengan syirkah atau syarikah merupakan akad kerjasama atau kemitraan antara dua pihak atau lebih pemilik modal yang mencampurkan modal mereka untuk tujuan mencari keuntungan. Semua pihak dalam kemitraan ini sama-sama menyediakan modal untuk membiayai suatu usaha tertentu, baik yang sudah berjalan atau baru. Anggota kemitraan ini dapat mengembalikan modal tersebut berikut bagi hasil yang telah disepakati secara bertahap atau sekaligus kepada mitra yang lainnya. Pembiayaan musyarakah dapat diberikan dalam bentuk kas, setara dengan kas, atau aktiva non-kas, termasuk aktiva tidak 


\section{Vol 1. No II}

berwuwjud seperti lisensi dan hak paten. Setiap mitra dapat meminta mitra lainnya untuk menyediakan jaminan atas kelalaian atau kesalahan yang disengaja berupa pelanggaran terhadap akad, seperti penyalahgunaan dana pembiayaan, manipulasi biaya dan pendapatan operasional, serta pelaksanaan yang tidak sesuai dengan prinsip syariah. Musyarakah dapat bersifat permanen maupun menurun. Dalam musyarakah permanen, bagian modal setiap mitra ditentukan sesuai akad dan jumlahnya tetap hingga akhir masa akad. Sedangkan dalam musyarakah menurun, bagian modal dari salah satu mitra akan dialihkan secara bertahap kepada mitra lainnya sehingga bagian modal salah satu mitra tadi akan menurun pada akhir masa akad, mitra lainnya tersebut akan menjadi pemilik usaha.

Pembiayaan musyarakah diakui pada saat pembayaran tunai atau penyerahan aktiva nonkas kepada mitra musyarakah. Pembiayaan dalam bentuk kas dinilai sebesar jumlah yang dibayarkan, sedangkan dalam bentuk aktiva non-kas dinilai sebesar nilai wajar dan jika terdapat selisih antara nilai wajar dan nilai buku aktiva non-kas, maka selisih tersebut diakui sebagai keuntungan atau kerugian bank pada saat penyerahan. Biaya yang dikeluarkan akibat akad misalnya biaya studi kelayakan tidak dapat diakui sebagai bagian pembiayaan musyarakah kecuali ada persetujuan dari seluruh mitra.

Laba musyarakah dapat dibagi secara proporsional sesuai dengan modal yang disetorkan (baik berupa kas maupun aktiva lainnya) atau sesuai nisbah yang disepakati bersama. Sementara rugi dibebankan secara proporsional sesuai dengan modal yang disetorkan (baik berupa kas maupun aktiva lainnya). Dalam pembiayaan musyarakah permanen dan menurun, setelah melewati satu periode pelaporan, maka laba diakui dalam periode terjadinya sesuai dengan nisbah bagi hasil yang disepakati. Sedangkan bila rugi, dalam pembiayaan musyarakah permanen, maka rugi diakui dalam periode terjadinya kerugian tersebut dan mengurangi pembiayaan musyarakah. Sementara dalam musyarakah menurun, rugi diakui dalam periode terjadinya secara proporsional sesuai dengan kontribusi modal dan mengurangi pembiayaan musyarakah. Pada saat terjadi kerugian dalam musyarakah akibat kelalaian atau kesalahan mitra pengelola usaha musyarakah, maka rugi tersebut ditanggung oleh mitra pengelola usaha. Rugi akibat kelalaian mitra tersebut diperhitungkan sebagai pengurang modal mitra pengelola usaha, kecuali bila mitra mengganti kerugian tersebut dengan dana baru. 


\section{Vol 1. No II}

Bila terjadi perselisihan dalam kemitraan ini sementara tidak ada kesepakatan antara pihak yang bersengketa, maka kesalahan yang disengaja harus dibuktikan berdasarkan badan arbitrase atau pengadilan (PSAK Nomor 59, Akuntansi Perbankan Syariah, 2002).

\section{Murabahah}

Murabahah merupakan akad jual beli barang dengan menyatakan harga perolehan dan keuntungan (margin) yang disepakati oleh penjual dan pembeli. Pembayaran murabahah dapat secara tunai atau cicilan. Perbedaan harga barang yang diperjualbelikan diperkenankan untuk cara pembayaran yang berbeda. Penjual dapat memberikan potongan bila pembeli mempercepat pembayaran, atau melunasi piutang sebelum jatuh tempo. Harga yang disepakati dalam murabahah adalah harga jual sedangkan harga beli harus diberitahukan. Apabila penjual mendapat potongan dari pemasok, maka potongan tersebut merupakan hak pembeli, namun bila potongan terjadi setelah akad, maka pembagian potongan tersebut dilakukan berdasarkan perjanjian dalam akad. Penjual dapat meminta nasabah menyediakan agunan atas piutang murabahah, antara lain dalam bentuk barang yang telah dibeli dari penjual. Penjual juga dapat meminta urbun sebagai uang muka pembelian pada saat akad bila kedua pihak bersepakat. Urbun menjadi bagian pelunasan piutang murabahahbila jadi dilaksanakan, tetapi bila murabahah tidak jadi dilaksanakan, maka urbundikembalikan kepada nasabah setelah dikurangi dengan kerugian sesuai dengan kesepakatan. Jika uang muka lebih kecil daripada kerugian penjual, maka penjual dapat meminta tambahan dari pembeli. Dari sisi penjual, urbun diakui sebagai uang muka pembelian sebesar jumlah yang diterima penjual saat diterima. Urbun diakui sebagai pembayaran piutang pada saat barang jadi dibeli pembeli (PSAK Nomor 59, Akuntansi Perbankan Syariah, 2002).

Pada sat pembeli tidak memenuhi piutang murabahah sesuai dengan akad, maka penjual berhak mengenakan denda, bila dapat dibuktikan bahwa pembeli tidak mampu melunasinya. Denda diterapkan bagi pembeli mampu yang menunda pembayaran. Denda tersebut didasarkan pada pendekatan ta'zir, yaitu untuk membuat pembeli lebih disiplin terhadap kewajibannya. Besarnya denda sesuai dengan yang berasal dari denda diperuntukkan sebagai dana sosial (alqardhul hasan).

\section{Perusahaan dalam Konsep Islam dan Agency Problem}




\section{Journal Competency of Business}

\section{Vol 1. No II}

Tujuan perusahaan Islami adalah maksimisasi profit dan sekaligus maksimisasi kebahagiaan (al-falaah) dan kebaikan (al-tayyibah) dalam suasana yang penuh dengan persaudaraan (al-ukhuwwah). Perusahaan Islami akan senantiasa mempertimbangkan kepentingan masyarakat kebanyakan sebagai prioritasnya. Perusahaan akan merealisasikan tingkat profit yang rasional dan fair yang dapat digunakan untuk mencapai tujuan yang lebih penting, yaitu bekerja dengan baik untuk mendapat ridha dari Allah SWT. Perusahaan dengan konsep Islami dibatasi oleh aturan etika yang berasal dari syariah untuk menyediakan jumlah kebutuhan atau produk barang maupun jasa yang sangat diperlukan secara memadai pada harga yang lebih rendah yang memungkinkan semua anggota masyarakat mendapatkan produk tersebut. Pemilik modal, pengelola, tenaga kerja, supplier, konsumen, dan semua pihak terkait saling berinteraksi dan saling menguntungkan. Semua kepentingan stakholder senantiasa dilindungi.Ukuran keberhasilan usaha tidak saja diukur dengan peningkatan laba bersih per tahun atau peningkatan earningper share (EPS), tetapi juga diukur dari kemampuan perusahaan dalam memberikan jaminan layanan yang halal dan terbaik, adanya jenjang karir dan gaji yang fair, serta penggunaan produk yang ramah lingkungan.

Dalam konsep Islam harus senantiasa disadari bahwa kekuatan pendorong internal perusahaan terletak pada saling adanya kerjasama dan saling tanggung jawab antara tenaga kerja dengan pemilik modal. Tanpa adanya tanggung jawab yang tinggi dari semua pihak dalam perusahaan, maka akan sulit untuk mewujudkan tujuan perusahaan. Hak dan tanggung jawab dari semua bagian yang terlibat dalam kontrak harus ditentukan terlebih dahulu sebagai sifat dari kontrak tersebut. Untuk menjaga jalinan hubungan yang saling menguntungkan antara produsen dengan sumber daya manusianya, maka pengusaha harus memperhatikan kepentingan tenaga kerjanya. Pengusaha Islami dalam hal ini dapat saja misalnya menolak ketentuan yang sama atau penyeragaman dalam pengupahan bila pengupahan tersebut memang tidak layak dan tidak sesuai dengan profesionalitas atau jerih payahnya yang diberikan pada perusahaan, sementara perusahaan dalam kondisi mampu untuk memperbaiki kesejahteraannya. Hadis Nabi Muhammad SAW, "Bayarlah upah buruh sebelum kering keringatnya”harus dipahami bahwa hak atau reward tenaga kerja atas perjuangannya pada perusahaan harus sesegera mungkin diberikan. Demikian pula dengan reward tersebut harus sesuai atau proporsional dengan kualitas pekerjaan yang dihasilkan. Kualitas pekerjaan tersebut dapat dipahami dari kesan yang muncul dari kata 


\section{Journal Competency of Business}

2017 Vol 1. No II

sebelum kering keringatnya dalam hadis tersebut. Artinya pekerjaan yang dilakukan dengan penuh keseriusan, profesional, jujur, amanah yang digambarkan hingga mengeluarkan keringat tersebut harus betul-betul dihargai dengan baik.

Prinsip yang tidak boleh ditinggalkan pula dalam perusahaan dengan konsep Islam adalah bahwa kontrak usaha atau bisnis seperti mudharabah, musyarakah, bai-salam, istishnadan sebagainya harus benar-benar bebas dari riba, gharar, dan maysir. Perusahaan yang tidak dapat melepaskan diri dari ketiga hal tersebut akan tidak dapat mencapai tujuannya, yaitu maksimisasi profit dan sekaligus maksimisasi kebahagiaan (al-falaah) dan kebaikan (al-thayyibah) dalam suasana yang penuh dengan persaudaraan (al-ukhuwwah). Sebaliknya ke-mudharatan besar akan muncul sebagai konsekuensinya.

Namun demikian dalam praktiknya, perusahaan dengan prinsip syariah Islam juga sangat potensial menghadapi sejumlah agency problem, terutama dalam model mudharabah dan musyarakah, sebagaimana dialami oleh perusahaan konvensional yang muncul akibat informasi yang tidak seimbang (asymmetric information)dan tindakan pengawasan yang cukup berbiaya (costly monitoring). Dalam kasus bank syariah, bank akan kesulitan untuk menilai kualitas proyek dengan adanya keterbatasan informasi masa lalu. Informasi tentang aktifitas personal dan proyek yang dimiliki para peminjam tidak dapatmenjadi sinyal bagi bank karena setiap permohonan tentang profit-loss sharing diklaim sebagai proyek dengan kualitas tertinggi. Bank kesulitan dalam menentukan kualitas permohonan pembiayaan apalagi bila terdapat sumber pembiayaan lain yang banyak jumlahnya, sehingga sangat potensial muncul advers selection problem dalam hal ini. Kemudian, dalam kontrak profit-loss sharing dimungkinkan pihak peminjam menurunkan laba yang dilaporkan karena kewenangannya dalam pengendalian laporan. Penurunan tersebut dapat saja dilakukan dengan memasukkan beban pekerjaan tambahan, atau upaya-upaya lain dengan menggunakan dalih akuntansi. Bank akan mengeluarkan biaya yang besar untuk monitoring apakah laba yang dilaporkan tersebut sesuai dengan realisasinya dan mencerminkan aktivitas bisnis yang dilakukan oleh perusahaan yang dibiayai. Adanya asymmetric information ini akan membawa bank pada masalah moral hazard. Rentannya bank terhadap masalah moral hazard dan advers selection tersebut akan memperlemah posisi persaingan bank dengan pesaing konvensional lainnya, karena adanya beban biaya tambahan untuk mendapatkan informasi dan penaksiran proyek, serta biaya 


\section{Journal Competency of Business}

2017 Vol 1. No II

operasional. Faktor itu pulalah menurut laporan Association of Islamic Banks tahun 1996 yang merupakan salah satu penyebab profit-loss sharing hanya digunakan kurang dari 20 persen dari keseluruhan investasi yang dilakukan oleh bank Islam diseluruh dunia. Demikian juga dengan Islamic Development Bank (IDB) yang tidak banyak menggunakan profit-loss sharing dalam bisnis keuangannya, kecuali dalam sejumlah proyek dengan skala kecil (Humayon dan Presley, 2000). 
2017 Vol 1. No II

\section{Solusi mengatasi Agency Problem dalam Konsep Konvensional}

\section{Stockholder versus Manajer}

Manajer diangkat dan diberi kekuatan oleh pemegang saham untuk merealisasikan kepentingan para pemegang saham. Namun demikian dalam kenyataannya motivasi kepentingan manajer secara pribadi sering membuat seorang manajer perusahaan bertindak tidak sesuai dengan tujuan utama perusahaan tersebut, sehingga memunculkan ketegangan atau konflik kepentingan antara dua belah pihak tersebut (agency problem). Dalam perusahaan konvensional untuk mengatasi masalah antara stockholder dan manajer biasanya manajer di paksa untuk bertindak terbaik bagi kepentingan stockholder dalam mengelola perusahaan. Beberapa cara yang biasa dilakukan untuk tujuan tersebut, antara lain (lihat Brigham dan Gapenski 1997):

a. Pemberian kompensasi kepada manajer atas kinerja yang dicapainya. Bentuk kompensasi tersebut dapat berupa executive stock option, yaitu pemberian hak kepada manajer untuk membeli saham perusahaan di masa yang akan datang dengan harga yang telah ditentukan. Kemudian, performance shares, yaitu pemberian saham kepada manajemen atas pencapaian tujuan tertentu.

b. Ancaman kehilangan kedudukan serta adanya ancaman pengambilalihan perusahaan (takeover) yang memungkinkan terjadinya penggantian manajer sesuai dengan selera keinginan stockholder. Namun cara ini biasanya akan direspon oleh manajer dengan tindakan yang banyak diarahkan pada ekspansi atau membeli perusahaan lain untuk memperbesar skala perusahaan. Tindakan itu dilakukan dengan motif utama, untuk meningkatkan keamanan posisi manajer dari ancaman pengambil alihanperusahaan lain, karena skala perusahaan yang besar akan merepotkan perusahaan lain untuk takeover. Kedua untuk meningkatkan kekuasaan, status, serta gaji manajer. Ketiga, untuk menciptakan peluang atau kesempatan karir bagi manajer tingkat bawah dan menengah.

c. Golden parachutes, yaitu suatu kontrak antara stockholder dan manajer yang berisi jaminan bahwa manajer akan mendapat sejumlah kompensasi tertentu bila perusahaan dibeli oleh perusahaan lain atau ketika terjadi perubahan pengendalian perusahaan. 


\section{Vol 1. No II}

d. Poison pill, yaitu upayastockholder agar perusahaan tidak diambil alih oleh perusahaan lain dengan mengeluarkan hak penjualan saham atau obligasi pada harga tertentu, sehingga pembeli harus membeli pada tingkat harga yang telah ditentukan sebelumnya tersebut. Dalam kondisi ini, manajer akan merasa lebih aman dari ancaman pengambil alihan perusahaan.

Berkenaan dengan solusi yang menekankan pada insentif atau kompensasi tersebut terdapat bukti empiris yang cukup menarik. Dari sejumlah penelitian yang telah dilakukan seperti yang dilakukan oleh Canyan dan Leach (1994) dan Ogden dan Watson (1996) didapatkan hasil bahwa pendekatan insentif atau kompensasi saja ternyata tidak secara signifikan dapat menurunkan agency problem dalam perusahaan.

\section{Stockholder versus Bondholder}

Pada saat ekspansi usaha stockholder yang dibiayai dengan menggunakan dana hutang berhasil, maka hanya pemegang saham yang diuntungkan, kreditur tidak mendapatkan hasil ekspansi tersebut karena bunga kredit didasarkan pada resiko asset perusahaan apalagi bila perusahaan mengalami kegagalan. Faktor itulah yang mendorongnya untuk menaikkan tingkat keuntungan yang disyaratkan atas kredit yang diberikannya, serta pembatasan atau bahkan penutupan akses kredit bagi perusahaan penutupan akses kredit bagi perusahaan yang berakibat semakin kecilnya jumlah hutang yang diterima. Dalam perusahaan konvensional untuk mengatasi masalah antara stockholder dan bondholder pada dasarnya terletak pada keputusan manajer. Beberapa kebijakan yang direkomendasikan untuk mengatasi masalah tersebut, antara lain (lihat Brigham dan Gapenski 1997):

a. Manajer tidak mengambil suatu proyek besar yang lebih beresiko daripada yang diantisipasi oleh kreditur. Hal ini dikarenakan bila proyek berhasil maka keuntungan hanya akan dinikmati oleh stockholder, sementara bila gagal maka kreditur akan ikut menanggung kerugian yang timbul.

b. Manajer tidak menggunakan tambahan pinjaman dari kreditur untuk membeli kembali saham yang outstanding dalam upaya untuk menaikkan return on equity stockholder, karena akan merugikan kreditur. 


\section{Vol 1. No II}

c. Manajer harus bekerja secara fair terhadap kreditur sesuai dengan kesepakatan kredit yang dibuat, karena posisi manajer sebagai agen stockholder sekaligus agen kreditu sehingga harus berada dalam keseimbangan antara kepentingan dua belah pihak.

\section{Bagaimana Konsep Syariah Mengatasi Agency Problem}

1. Dari sudut pandang Islam, dikotomi antara pemilik perusahaan dan manajer dapat diselesaikan dengan baik. Dalam kasus mudharabah, pemilik aset adalah si pemilik perusahaan, sementara mudharib yang dalam hal ini manajer mempunyai kekuasaan pengambilan keputusan. Dasar hubungan antara kedua belah pihak adalah amanah atau mengemban kepercayaan yang diberikan pemilik pada mudharib. Mudharibadalah agen yang bekerja sesuai dengan yang diinginkan oleh pemilik dalam kerangka amanah tersebut. Dia akan mencoba bertindak lebih didasarkan pada kepentingan perusahaan daripada kepentingan diri sendiri. Prinsip kepercayaan bisnis dalam Islam sangat bertentangan dengan prinsip kepentingan pribadi yang sedemikian familiar dalam ekonomi pasar bebas yang berdasarkan liberalisme dan kapitalisme.

2. Bila didasarkan pada teori Modigliani-Miller, bahwa rasio hutang-modal perusahaan tidak mempunyai pengaruh yang signifikan pada tingkat output perusahaan atau pada nilai saham perusahaan, maka proposisi tersebut tidak dapat dimasukkan dalam rangka perusahaan Islami, karena adanya larangan terhadap bunga yang terkandung dalam hutang tersebut. Kalaupun hutang tersebut berupa penerbitan obligasi, maka obligasi ini juga dioperasionalkan dengan landasan syariah. Obligasi syariah ini tidak didasarkan pada bunga tetapi didasarkan pada bagi hasil, yang perhitungannya tidak sama dngan bunga sebagaimana yang dimasukkan dalam teori struktur modalnya Modigliani-Miller tersebut. Terlepas dari ketentuan syariah seperti itu, secara teori adanya beban bunga hutang akan semakin memperbesar biaya tetap yang dikeluarkan perusahaan, karena biaya bunga ini bersifat tetap berapapun jumlah output yang dihasilkan. Ketika jumlah biaya tetap (fixed cost) semakin besar, maka biaya tetap rata-rata per unit produk (average fixed cost) juga akan semakin esar, demikian pula dengan biaya rata-rata per unit (average cost). Besarnya biaya rata-rata per unit tersebut akan berpengaruh pada penentuan harga jual produk per unit yang semakin mahal karena karena perusahaan tidak mau rugi, dan membebankan kenaikan biaya ini pada konsumen melalui 


\section{Vol 1. No II}

penetapan harga jual produk. Dari sisi perusahaan pola pembiayaan dengan beban bunga tersebut tidak lebih menguntungkan bila dibandingkan dengan pola pembiayaan secara Islami. Perlu diingat bahwa pola pembiayaan Islami didasarkan dengan profit atau revenue sharing, yang artinya bagi hasil tersebut tidak membebani biaya tetap atau biaya variabel. Implikasi selanjutnya dari penetapan harga jual produk yang tinggi akibat beban bunga tersebut dapat mengurangi daya saing produk perusahaan di pasar, terutama dari sisi harga. Manfaat besar pada skala mikro dari pola pembiayaan Islami yang terkait langsung dengan bentuk usaha tersebut juga akan berdampak positif dalam skala makro. Dalam kerangka ekonomi makro adanya tambahan beban tetap di sektor riil tersebut berdampak pada pendapatan riil masyarakat yang semakin rendah ketika terjadi penetapan harga jual produk yang lebih tinggi, sementara tidak diikuti dengan kenaikan pendapatan nominalnya. Pendapatan riil masyarakat yang menurun ini akan berdampak pada semakin mengecilnya permintaan produk, sehingga agregat demand akan mengalami kemerosotan. Dengan kata lain kondisi tersebut akan mengganggu pertumbuhan ekonomi suatu negara.

Dalam hal ini, Badal Mukherjee dari hasil studinya sebagaimana dikutip oleh Sarker (1999) menunjukkan bahwa tingkat suku bunga nol persen dalam suatu perekonomian ternyata menghasilkan keseimbangan dengan tingkat pertumbuhan yang lebih tinggi dan profit margin yang lebih rendah daripada dalam suatu perekonomian dengan pemberlakuan tingkat bunga yang positif. Demikian pula masih dalam kerangka ekonomi makro, akan sangat besar penghematan yang dapat dilakukan secara nasional bila perusahaan-perusahaan di sektor riil dalam pembiayaannya tidak menggunakan pola hutang yang mengandung bunga tersebut. Masyarakat konsumen tidak perlu mengeluarkan uang yang besar untuk mendapatkan produk yang diinginkannya di pasar. Tabungan atau kekuatan modal yang berasal dari dalam negeri, yaitu dari masyarakat akan semakin besar ketika harga jual produk-produk menjadi lebih murah. Tabungan nasional yang besar ini akan sangat berguna untuk menggerakkan perekonomian nasional secara mandiri yang lebih kokoh, dan tidak tergantung kepada negara lain. Dengan demikian kesulitan keuangan nasional sebenarnya sangat mungkin dapat diatasi dengan pola pembiayaan usaha secara Islami yang bebas dari bunga tersebut. 


\section{Vol 1. No II}

3. Masalah pemilik dengan manajer (principal-agent) dapat diminimumkan dalam sistem Profit Loss Sharing. Hal ini dikarenakan reward yang ditentukan yang diorientasikan untuk dapat saling bekerja sama akan mempengaruhi agent untuk berperilaku jujur.

4. Menurut sejumlah peneliti terdapat dua alasan mengapa masalah pemilik dengan manajer (principal agent) akan menjadi minimum dalam ekonomi bisnis Islami. Pertama, orang Islam percaya pada konsep keabadian hidup, dimana kejujuran akan dibalas dengan pahala, sementara ketidak jujuran akan dibalas dengan hukuman. Itu merupakan insentif non-material bagi orang yang berbuat jujur. Kedua, jika semua kegiatan operasi keuangan didasarkan pada syariah, pengusaha-pengusaha yang menjunjung tinggi kejujuran akan mendorong pengusaha-pengusaha yang tidak jujur keluar dari pasar, sehingga mereka yang berbuat curang tidak akan mendapatkan akses. Dalam hal ini, sekali lagi terdapat insentif keuangan bagi mereka yang berbuat jujur (Bashir dalam Sarker, 1999).

5. Format kontrak didesain secocok dan sejujur mungkin di depan dengan memasukkan sejumlah mekanisme insentif khusus, seperti penyediaan jatah bagi kepemilikan melalui pemberian saham bonus atas kinerja yang dicapai, dan sebagainya, sehingga akan mampu mengurangi masalah keagenan. Ini dikarenakan agen akan semakin terakomodasi atau terikat dalam struktur kepemilikan perusahaan.

6. Profit-Loss Sharing dapat secara efektif digunakan untuk memunculkan atau mempromosikan para pengusaha melalui sejumlah proyek. Khusus dalam bank Islam, bank dalam kasus ini dapat menjalankan suatu proyek dengan pengusaha-pengusaha infant, dan secara bertahap mentransfer kepemilikan mereka dalam kasus mudharabah, serta kepemilikan yang dibagi dalam kasus musyarakah kepada para wirausahawan. Proses seperti ini dapat menyediakan insentif untuk mengurangi masalah moral hazard dalam usaha-usaha yang ditangani bank Islam.

7. Dalam perbankan, hubungan yang terjalin panjang antara pihak bank dengan pengguna modal akan dapat meningkatan efisiensi bank yang berdasarkan profit-loss sharing dengan cara berbeda. Hubungan yang terus-menerus antara dua belah pihak tersebut akan mengurangi biaya monitoring karena bank menjadi lebih mengenal sistem auditing yang 


\section{Journal Competency of Business}

\section{Vol 1. No II}

digunakan oleh pengguna modal, serta akan sangat memahami transaksi mereka dalam periode panjang.

Hal tersebut akan dapat digunakan untuk mengembangkan penilaian yang akurat dari kinerja pengguna modal secara relatif terhadap perusahaan-perusahaan lain dalam sektor atau ruang lingkup yang sama, sehingga akan dapat diketahui dengan lebih baik apakah rendahnya return yang dilaporkan merupakan hasil dari inefisiensi pengguna modal, penipuan, atau adanya penurunan yang terjadi secara sektoral.

8. Dalam bank, pengawasan pinjaman yang dilakukan secara aktif dalam sistem bank yang bercabang merupakan suatu peluang untuk meminimumkan asymmetric information antara pihak bank dan pengguna modal. Petugas-petugas bank Islam yang bekerja dan hidup di wilayah lingkungan usaha pengguna modal, memungkinkannya untuk menaksir reputasi pengguna modal, dan dapat menginspeksi kegiatan operasi usaha dengan lebih mudah dan terbuka. Dengan demikian masalah keagenan akan dapat diminimumkan secara subtansial. Meskipun aktifitas seperti ini dapat meningkatkan sejumlah biaya pengawasan, namun hasilnya diharapkan akan lebih baik daripada dalam situasi pinjaman tanpa pengawasan.

9. Pada prinsipnya, secara syariah dibenarkan menggunakan konsep konvensional dalam penyelesaian agency problem sebagaiman disebutkan diatas, sepanjang cara tersebut baik dan dibenarkan dalam kerangkan syariah.

10. Untuk memperbaiki mekanisme kontrol dalam kasus mudharabah agar financier lebih mempunyai hak, maka dipandang perlu merekontruksi standar kontrak profit-loss sharing sesuai dengan kebutuhan dan kondisi yang dihadapi di lapangan, namun masih dalam kerangka syariah yang diperbolehkan. 


\section{Vol 1. No II}

\section{Kesimpulan}

Dari paparan diatas nampak bahwa agency problem dapat saja dialami perusahaan dengan konsep konvensional maupun yang berdasarkan syariah.sejumlah solusi ditawarkan untuk mengatasi masalah keagenan ini. Dalam menawarkan solusi ini terdapat perbedaan antara konsep konvensional dan konsep syariah Islam. Dalam konsep konvensional penyelesaian masalah hanya didekati dengan pendekatan yang bersifat materi atau insentif yang berorientasi pada keduniaan semata. Dari hasil sejumlah penelitian yang telah dilakukan dapat disimpulkan bahwa pendekatan insentif saja tidak secara signifikan dapat menurunkan agency problem dalam perusahaan (Canyan dan Leach, 1994; Ogden dan Watson, 1996). Artinya bahwa pendekatan insentif atau materi tidak cukup untuk mengatasi agency problem dengan efektif, secanggih apapun bentuk dan cara yang digunakannya.

Sementara itu dalam konsep syariah proses penyelesaian agency problem dilakukan sejak dari awal suatu kontrak bisnis disepakati dengan dasar saling percaya dan amanah.Pendekatan yang digunakan tidak saja materi tetapi juga yang bersifat non-materi, yang berorientasi pada dunia-akherat. Namun demikian, dalam praktiknya seiring dengan belum dilaksanakan syariat secara sempurna oleh pihak-pihak yang terlibat dalam kontrak bisnis, maka agency problem tetap saja menghantui perusahaan dengan konsep syariah karena kemungkinan munculnya asymmetric information.Dengan demikian dipandang perlu memperbaiki standar kontrak profitloss sharing sesuai dengan kebutuhan dan kondisi yang dihadapi di lapangan sebagai pelengkap. Dengan catatan upaya tersebut tidak melanggar syariah sehingga mampu meminimalkan agency problem. Keberhasilan dari upaya yang terakhir tersebut akan semakin membuat konsep syariah unggul dalam penyelesaian agency problem, karena sistem pengendalian moral hazard tidak saja muncul dari aturan yang dibuat namun juga berasal dari diri semua pihak yang bersepakat dalam kontrak secara inheren. Tercapainya efisiensi biaya pengawasan yang lebih tinggi secara teori sangat mungkin dapat terwujud dengan konsep syariah ini. 


\section{Journal Competency of Business}

2017 Vol 1. No II

\section{DAFTAR PUSTAKA}

Eugene F. Brigham, Louis C. Gapenski, Financial Management: Theory And Practice, Eight Edition, The Dryden Press Harcourt Brace College Publishers, 1997.

Humayon A. Dar, John R. Presley, "Lack Of Profit-Loss Sharing In Islamic Banking: Management Nad Control Imbalances", International Journal Of Islamic Financial Services, Vol. 2, No. 2, 2000.

Ikatan Akuntan Indonesia, Pernyataan Standar Akuntansi Keuangan Nomor 59: Akuntansi Perbankan Syariah, Salemba Empat, 2002.

M. Canyan, D. Leach, “Top Pay, Company Performance And Corporate Governance”, Oxford Bulletin Economics And Statistics, 1994.

M.C. Jensen, W. Meckling, "Theory Of The Firm: Managerial Behavior, Agency Costs, And Ownership Stucture”, Journal Of Financial Economics, 1976.

Md. Abdul Awwal Sarker, "Islamic Business Contracts, Agency Problem And The Theory Of The Islamic Firm", International Journal Of Islamic Financial Services, Vol. 1, No.2, July-September 1999.

M. Umer Chapra, Toward A Just Monetary System, The Islamic Foundation, Licester, 1985.

S. Ogden, R. Watson, "The Relationship Between Changes In Incentive Stuctures, Executive Pay And Corporate Performance: Some Evidence From The Privatised Water Industry In England And Wales", Journal Of Buiness Finance And Accounting, 1996. 